\title{
A CONVENIENT AND HIGHLY EFFICIENT SYNTHESIS OF ONE KIND OF PEPTIDE NUCLEIC ACID MONOMER
}

\author{
Xuemei Tang ${ }^{1,2}$, Guangxia Tang ${ }^{1}$, Hang Wang ${ }^{1}$, Lingfei Luo ${ }^{2}$ and Dacheng Yang ${ }^{1 *}$ \\ ${ }^{1}$ School of Chemistry and Chemical Engineering, Southwest University, Chongqing, 400715, \\ China \\ ${ }^{2}$ Laboratory of Molecular Developmental Biology, School of Life Science, Southwest \\ University, Chongqing, 400715, China
}

(Received May 20, 2011; revised July 4, 2012)

\begin{abstract}
S$-Thyminyl- $L$-cysteine methyl ester hydrochloride (compound 1), a non-classical peptide nucleic acid monomer, was synthesized through the key intermediate, $N$-tert- butoxycarbonyl- $S$-thyminyl- $L$-cysteine (compound 3), which afforded from the reaction of $S$-thyminyl- $L$-cysteine hydrochloride (compound 2) with ditert-butyl dicarbonate $\left(\mathrm{Boc}_{2} \mathrm{O}\right)$. This was followed by the esterification and deprotection of compound $\mathbf{3}$ at an overall yield of $82 \%$. The mixture of thionyl chloride and methanol was found as an efficient reagent for simultaneous deprotection of tert-butoxycarbonyl (Boc) group and esterification of carboxy group of compound 3. This high-yield two-step method was also applied to other analogues of compound 1 successfully. The chemical structures of four new compounds $(\mathbf{5 a - 5 d})$ were confirmed by ${ }^{1} \mathrm{H}$ NMR and ${ }^{13} \mathrm{C}$ NMR.
\end{abstract}

KEY WORDS: Thionyl chloride, Esterification, Deprotection, Peptide nucleic acid

\section{INTRODUCTION}

Peptide nucleic acid (PNA), a DNA mimic with pseudo peptide backbone, was introduced by Nielsen in 1991 [1], and is still attracting broad attention from both chemists and biologists due to its superior characters, such as the stronger specificity and selectivity of binding towards complementary DNA and RNA [2, 3]. Over the past two decades, a growing number of PNA derivatives have been synthesized and successfully applied in molecular biology, diagnostics and therapeutics [4-7]. Recently, a novel non-classical PNA monomer, $S$-thyminyl- $L$-cysteine hydrochloride (compound 2), which consists of natural chiral cysteine and 5-hydroxymethyluracil [8], was reported by $\mathrm{Yu}$ and his co-workers [9, 10]. Compound $\mathbf{2}$ can be conveniently conjugated with certain cyclens, and the resulting PNA monomer-cyclen conjugates can bind metal ions and show moderate catalytic activity on DNA cleavage [10]. For further study the activity of other peptides containing this PNA monomer, $S$-thyminyl- $L$-cysteine methyl ester hydrochloride (compound 1) is an important intermediate. Up to now, however, only one method was developed to synthesize the intermediate with low yield of $40 \%$ (Route A, Scheme 1) [11]. Therefore, it is highly desirable to develop a new effective method for preparation of compound 1. Herein, we wish to report a new synthetic route which gave the compound $\mathbf{1}$ with the overall yield of $82 \%$ (Route C, Scheme 1).

\footnotetext{
*Corresponding author. E-mail: hxydc@swu.edu.cn
} 

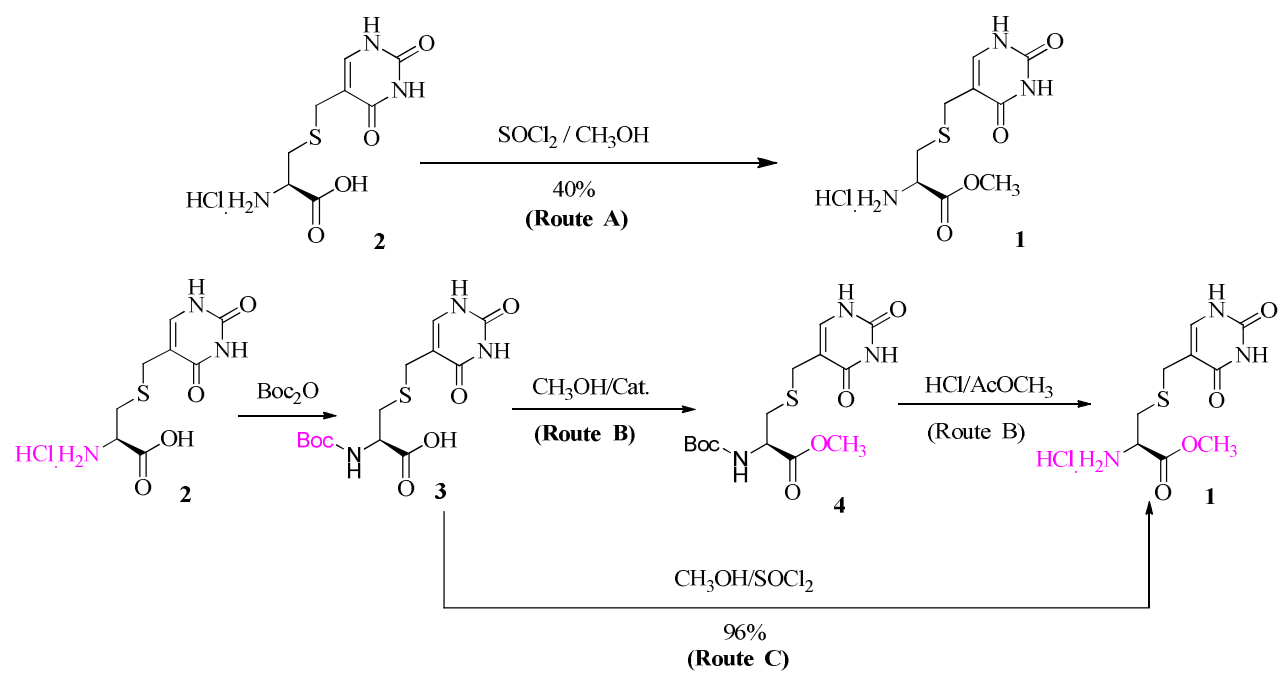

Scheme 1. Reported and designed preparative routes of compound $\mathbf{1}$.

\section{EXPERIMENTAL}

\section{Measurements}

Melting points were detected by X-6 sophisticated micro-melting point apparatus. The ${ }^{1} \mathrm{H}$ NMR and ${ }^{13} \mathrm{C}$ NMR spectra were recorded on a Bruker AV300 spectrometer in $\mathrm{D}_{2} \mathrm{O}-d_{2}$ with tetramethylsilane (TMS) as an internal standard. The data of electro-spray ionization mass spectrum (ESI MS) was obtained on an Agilent 1946B instrument. IR spectra were carried out on Perkin-Elmer, Spectrum GX, USA, using $\mathrm{KBr}$ pellets. The progress of the reactions was monitored by thin-layer chromatography (TLC).

\section{General procedure for synthesis}

The compound 2 was prepared according to the previously reported method [9] in the range of $83-91 \%$ yield. Its chemical structure was identified by IR and ESI MS.

Synthesis of N-tert-butoxycarbonyl-S-thyminyl-L-cysteine (compound 3). Compound 2 (8.445 g, $30 \mathrm{mmol}$ ) was added to an aqueous solution of potassium hydroxide $(5.601 \mathrm{~g}, 100.0 \mathrm{mmol})$. The solution was cooled to $0{ }^{\circ} \mathrm{C}$ in ice bath with vigorous stirring. Then the acetone solution (20 $\mathrm{mL})$ of di-tert-butyl dicarbonate $\left(\mathrm{Boc}_{2} \mathrm{O}\right)(9.845 \mathrm{~g}, 45 \mathrm{mmol})$ was added dropwise. After being kept in ice bath for $2 \mathrm{~h}$, the solution was allowed to warm up to ambient temperature. The reaction progress was monitored by TLC $\left(\mathrm{CHCl}_{3}: \mathrm{CH}_{3} \mathrm{OH}=4: 1, \mathrm{v} / \mathrm{v}\right)$. After the reaction completed, the mixture was concentrated under reduced pressure to remove the acetone. Then excess $\mathrm{Boc}_{2} \mathrm{O}$ was removed by extracting with ether $(3 \times 30 \mathrm{~mL})$, and the $\mathrm{pH}$ was adjusted to $3-4$ with $2 \mathrm{~N} \mathrm{HCl}$ in ice bath. Compound $3(8.789 \mathrm{~g})$ was obtained as a white powder through filtering, washing with water $(2 \times 20 \mathrm{~mL})$ and drying over $\mathrm{P}_{2} \mathrm{O}_{5}$ in vacuum. m.p. $120.3-121.2{ }^{\circ} \mathrm{C}$ (lit. $118-119{ }^{\circ} \mathrm{C}[9]$ ). 
Synthesis of S-thyminyl-L-cysteine methyl ester hydrochloride (compound 1). Thionyl chloride $\left(\mathrm{SOCl}_{2}, 5 \mathrm{~mL}\right)$ was added dropwise to methanol $\left(50 \mathrm{~mL}, 0{ }^{\circ} \mathrm{C}\right)$ in a round-bottom flask. The solution was stirred for $0.5 \mathrm{~h}$ in ice bath, prior to the addition of compound $3(8.625 \mathrm{~g}, 25$ mmol). The temperature of this reaction mixture was allowed to rise to ambient temperature. The progress was monitored by TLC $\left(\mathrm{CHCl}_{3}: \mathrm{CH}_{3} \mathrm{OH}=4: 1\right.$, v/v). Upon completion, the resulting mixture was concentrated under reduced pressure to remove methanol and the obtained crude product was scattered in ether for approximately $2 \mathrm{~h}$ at ambient temperature. The analytically pure compound $\mathbf{1}$ then was collected by filtration as a white powder.

Synthesis of compounds $\mathbf{5 a - 5 d}$. Thionyl chloride $(6 \mathrm{mmol})$ was added dropwise to the selected alcohol (ethanol, 1-propanol, 1-butanol or 1-pentanol) $(5 \mathrm{~mL})$ in a round-bottom flask at $0{ }^{\circ} \mathrm{C}$. After keep stirring for $0.5 \mathrm{~h}$, compound $3(2 \mathrm{mmol})$ was added. The progress was monitored by TLC $\left(\mathrm{CHCl}_{3}: \mathrm{CH}_{3} \mathrm{OH}=4: 1, \mathrm{v} / \mathrm{v}\right)$, the temperature of this solution was allowed to rise to $45-50$ ${ }^{\circ} \mathrm{C}$. After completion of the reaction, appropriate amount of petroleum ether was added to precipitate the target compounds, and finally the white solid was collected by filtration and dried in vacuo to give the analytically pure compounds $\mathbf{5 a - 5 d}$, respectively.

\section{RESULTS AND DISCUSSION}

Initial study was undertaken using the reported one-step method (Route A, Scheme 1). Comparable to the literature [11], the same result was obtained and the target compound was gained only in $40 \%$ yield with tedious workup. On the assumption that the low yield was probably attributed to the poor solubility of compound $\mathbf{2}$ in methanol, we designed a new synthetic method (Route B, Scheme 1). The synthesis of compound $\mathbf{1}$ in route B was accomplished through three-step sequence. Protection of 2 with $\mathrm{Boc}_{2} \mathrm{O}$ produced 3 [12] which was converted into $\mathbf{4}$ through esterification. Finally, removal of the Boc group produced 1 [13]. Indeed, the solubility of compound $\mathbf{3}$ in methanol was improved substantially. The esterification of carboxy group of compound $\mathbf{3}$ and the deprotection of Boc group of compound $\mathbf{4}$, unexpectedly, took place simultaneously in the mixture of thionyl chloride and methanol, as such the compound $\mathbf{1}$ was gained from compound $\mathbf{3}$ in one-step rather than two-step reaction. Thus, we found a high-yield two-step synthetic method of compound $\mathbf{1}$ (Route C, Scheme 1).

To obtain compound 3 in high yield, we selected $\mathrm{Boc}_{2} \mathrm{O}$ as the protecting reagent. As shown in Table 1, the reaction of compound $2(30 \mathrm{mmol}), \mathrm{Boc}_{2} \mathrm{O}(45 \mathrm{mmol})$ and $\mathrm{KOH}(100 \mathrm{mmol})$ gave the product with the yield of $85 \%$ (entry 3 ).

Table 1. The synthetic results of compound 3 .

\begin{tabular}{|c|c|c|c|c|c|c|}
\hline \multirow{2}{*}{ Entry } & \multicolumn{3}{|c|}{ Reactants $(\mathrm{g} / \mathrm{mmol})$} & \multirow{2}{*}{ Time (h) } & \multirow{2}{*}{ Weight (g) } & \multirow{2}{*}{$\begin{array}{c}\text { Yield } \\
(\%)\end{array}$} \\
\hline & 2 & $\mathrm{Boc}_{2} \mathrm{O}$ & $\mathrm{KOH}$ & & & \\
\hline 1 & $0.562 / 2$ & $0.542 / 2.4$ & $0.337 / 6.0$ & 24 & 0.484 & 70 \\
\hline 2 & $5.610 / 20$ & $5.410 / 24$ & $3.370 / 60.0$ & 20 & 5.729 & 83 \\
\hline 3 & $8.445 / 30$ & $9.845 / 45$ & $5.601 / 100.0$ & 23 & 8.798 & 85 \\
\hline
\end{tabular}

Considering the importance of the step in esterification of carboxy group and removal of Boc group in compound $\mathbf{3}$, we mainly investigated the effect of molar ratio of compound $\mathbf{3}$ to $\mathrm{SOCl}_{2}$ on the reaction. As shown in Table 2, the molar ratio of $3 / \mathrm{SOCl}_{2}$ had a remarkable influence on the yield. When the ratio of $3 / \mathrm{SOCl}_{2}$ was changed from $1 / 0.4$ to $1 / 0.6$ (entry 1 and 2 ), the compound $\mathbf{3}$ was not converted into the compound $\mathbf{1}$ completely. When the ratio surpassed 1/0.8 (entry 3-9), the conversion of compound $\mathbf{3}$ performed completely and the yield was up to $80-91 \%$. Along with larger ratio of $\mathbf{3} / \mathrm{SOCl}_{2}$, the reaction afforded compound $\mathbf{1}$ in 
higher yield in shorter reaction time. And then the large scale preparation of compound $\mathbf{1}$ was carried out in the best yield of $96 \%$ within 6 hours (entry 11).

Table 2. The synthetic results of compound $\mathbf{1}$.

\begin{tabular}{|c|c|c|c|c|c|c|c|}
\hline Entry & $\begin{array}{c}\text { Scale } \\
(\mathrm{mmol})\end{array}$ & $\begin{array}{c}\mathbf{3} \\
(\mathrm{g} / \mathrm{mmol})\end{array}$ & $\begin{array}{c}\mathrm{SOCl}_{2} \\
(\mathrm{~mL} / \mathrm{mmol})\end{array}$ & $\begin{array}{c}3 / \mathrm{SOCl}_{2} \\
\text { molar ratio }\end{array}$ & $\begin{array}{c}\text { Time } \\
(\mathrm{h})\end{array}$ & $\begin{array}{c}\text { Weight } \\
(\mathrm{g})\end{array}$ & $\begin{array}{c}\text { Yield } \\
(\%)\end{array}$ \\
\hline 1 & 4 & $1.380 / 4.0$ & $0.114 / 1.6$ & $1.0: 0.4$ & 43.0 & - & - \\
\hline 2 & 5 & $1.725 / 5.0$ & $0.213 / 3.0$ & $1.0: 0.6$ & 41.0 & - & - \\
\hline 3 & 5 & $1.728 / 5.0$ & $0.284 / 4.0$ & $1.0: 0.8$ & 41.0 & 1.181 & 80 \\
\hline 4 & 5 & $1.725 / 5.0$ & $0.391 / 6.0$ & $1.0: 1.2$ & 24.0 & 1.286 & 87 \\
\hline 5 & 5 & $1.727 / 5.0$ & $0.530 / 7.5$ & $1.0: 1.5$ & 21.7 & 1.326 & 90 \\
\hline 6 & 5 & $1.723 / 5.0$ & $0.710 / 10.0$ & $1.0: 2.0$ & 18.0 & 1.297 & 88 \\
\hline 7 & 5 & $1.735 / 5.0$ & $0.850 / 12.0$ & $1.0: 2.4$ & 19.0 & 1.340 & 91 \\
\hline 8 & 5 & $1.727 / 5.0$ & $0.920 / 13.0$ & $1.0: 2.6$ & 19.3 & 1.320 & 89 \\
\hline 9 & 5 & $1.725 / 5.0$ & $1.00 / 15.0$ & $1.0: 3.0$ & 15.0 & 1.344 & 91 \\
\hline 10 & 25 & $8.650 / 25.0$ & $5.00 / 75.0$ & $1.0: 3.0$ & 10.0 & 6.746 & 91 \\
\hline 11 & 25 & $8.630 / 25.0$ & $5.00 / 75.0$ & $1.0: 3.0$ & 6.0 & 7.130 & 96 \\
\hline
\end{tabular}

To expand upon the scope of the reaction, several other alcohols were also used. Generally, these alcohols afforded the corresponding products (5a-5d) in the yield of 75-90\% (Table 3) and the chemical structures of these new compounds have been confirmed by NMR. The result proved that the $\mathrm{SOCl}_{2}$-alcohol system is a general reagent for simultaneous deprotection of the Boc group and esterification of the carboxylic acid.

Table 3. The synthetic results of compound 5a-5d.

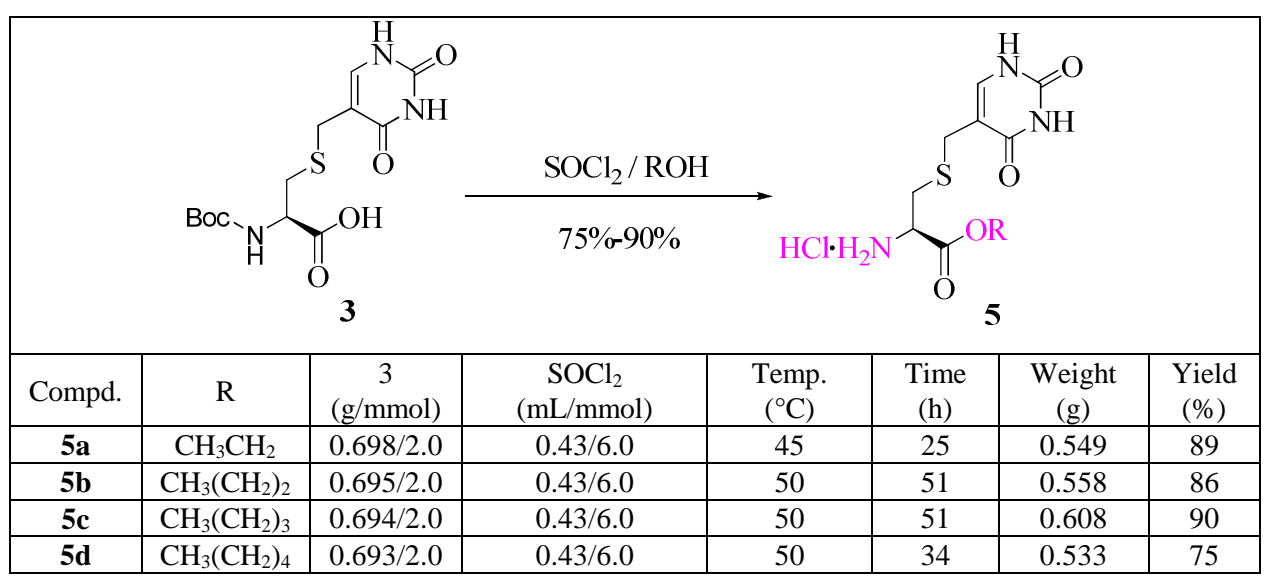

Characterization of compounds

Compound 1. m.p. 193.7-195.0 ${ }^{\circ}$ C; ESI MS: 260.1 ([M-Cl $\left.]^{+}, 100\right)$.

Compound 2. m.p. 239.3-241.3 ${ }^{\circ} \mathrm{C}$ (lit. $238-240{ }^{\circ} \mathrm{C}$ [9]). IR ( $\left.\mathrm{cm}^{-1}, \mathrm{KBr}\right): 3432,3268,3229$, 3073, 2966, 2816, 1752, 1722, 1701, 1638, 1175; ESI MS: $\mathrm{m} / \mathrm{z}=268.0[\mathrm{M}+\mathrm{Na}-\mathrm{HCl}]^{+} ; \mathrm{m} / \mathrm{z}=$ $246.0[\mathrm{M}+\mathrm{H}-\mathrm{HCl}]^{+}$. 
The compounds 5a-5d were characterized by ${ }^{1} \mathrm{H}$ NMR, ${ }^{13} \mathrm{C}$ NMR. Spectral and analytical data are as follows.

5a. White powder; m.p. 217.3-219.7 ${ }^{\circ} \mathrm{C} ;{ }^{1} \mathrm{H}$ NMR $\left(\mathrm{D}_{2} \mathrm{O}, 300 \mathrm{MHz}\right) \delta: 1.17(\mathrm{t}, 3 \mathrm{H}, J=7.2 \mathrm{~Hz}$, $\mathrm{CH}_{2} \mathrm{CH}_{3}$ ), $2.93\left(\mathrm{dd}, 1 \mathrm{H}, J=7.8,15 \mathrm{~Hz}, \mathrm{CH}_{2} \mathrm{CH}\right), 3.10$ (dd, $\left.1 \mathrm{H}, J=4.8,15 \mathrm{~Hz}, \mathrm{CH}_{2} \mathrm{CH}\right), 3.40$ (s, $\left.2 \mathrm{H}, \mathrm{SCH}_{2}\right), 4.15-4.22\left(\mathrm{~m}, 2 \mathrm{H}, \mathrm{OCH}_{2}\right), 4.26-4.29(\mathrm{~m}, 1 \mathrm{H}, \mathrm{CH}), 7.46(\mathrm{~s}, 1 \mathrm{H}$, thymine-6-CH $) ;{ }^{13} \mathrm{C}$ NMR $\left(\mathrm{D}_{2} \mathrm{O}, 75 \mathrm{MHz}\right) \delta: 168.6,165.8,152.8,141.0,109.5,63.9,52.4,31.0,27.5,13.2$.

5b. White powder; m.p. 205.6-208.5 ${ }^{\circ} \mathrm{C} ;{ }^{1} \mathrm{H}$ NMR $\left(\mathrm{D}_{2} \mathrm{O}, 300 \mathrm{MHz}\right) \delta$ : $0.80(\mathrm{t}, 3 \mathrm{H}, J=7.2 \mathrm{~Hz}$, $\left.\mathrm{CH}_{2} \mathrm{CH}_{3}\right), 1.51-1.63\left(\mathrm{~m}, 2 \mathrm{H}, \mathrm{CH}_{2} \mathrm{CH}_{3}\right), 2.95\left(\mathrm{dd}, 1 \mathrm{H}, J=7.2,14.7 \mathrm{~Hz}, \mathrm{CH}_{2} \mathrm{CH}\right), 3.10$ (dd, $1 \mathrm{H}, J$ $\left.=4.5,15 \mathrm{~Hz}, \mathrm{CH}_{2} \mathrm{CH}\right), 3.41\left(\mathrm{~s}, 2 \mathrm{H}, \mathrm{SCH}_{2}\right), 4.10\left(\mathrm{t}, 2 \mathrm{H}, J=6.6 \mathrm{~Hz}, \mathrm{OCH}_{2}\right), 4.29-4.32(\mathrm{~m}, 1 \mathrm{H}$, $\mathrm{CH}), 7.47\left(\mathrm{~s}, 1 \mathrm{H}\right.$, thymine-6-CH) ${ }^{13} \mathrm{C}$ NMR $\left(\mathrm{D}_{2} \mathrm{O}, 75 \mathrm{MHz}\right) \delta: 168.7,165.7,152.7,141.0,109.5$, $69.2,52.4,31.0,27.5,21.2,9.6$.

5c. White powder; m.p. 163.1-166.7 ${ }^{\circ} \mathrm{C} ;{ }^{1} \mathrm{H}$ NMR $\left(\mathrm{D}_{2} \mathrm{O}, 300 \mathrm{MHz}\right) \delta: 0.76(\mathrm{t}, 3 \mathrm{H}, J=7.5 \mathrm{~Hz}$, $\mathrm{CH}_{3}$ ), 1.17-1.29 (m, 2H, $\mathrm{CH}_{2} \mathrm{CH}_{3}$ ), 1.48-1.57 (m, 2H, $\mathrm{CH}_{2} \mathrm{CH}_{2} \mathrm{CH}_{3}$ ), 2.94 (dd, $1 \mathrm{H}, J=7.5,15.3$ $\mathrm{Hz}, \mathrm{CH}_{2} \mathrm{CH}$ ), 3.08 (dd, $1 \mathrm{H}, J=4.2,14.7 \mathrm{~Hz}, \mathrm{CH}_{2} \mathrm{CH}$ ), 3.40 (s, 2H, $\mathrm{SCH}_{2}$ ), 4.14 (t, 2H, $J=6.0$ $\left.\mathrm{Hz}, \mathrm{OCH}_{2}\right), 4.27-4.31(\mathrm{~m}, 1 \mathrm{H}, \mathrm{CH}), 7.46\left(\mathrm{~s}, 1 \mathrm{H}\right.$, thymine-6-CH); ${ }^{13} \mathrm{C}$ NMR $\left(\mathrm{D}_{2} \mathrm{O}, 75 \mathrm{MHz}\right) \delta$ : $166.5,163.5,150.5,138.8,107.3,65.2,50.1,28.8,27.5,25.2,16.2,10.6$.

5d. White powder; m.p. 189.0-191.8 ${ }^{\circ} \mathrm{C} ;{ }^{1} \mathrm{H}$ NMR $\left(\mathrm{D}_{2} \mathrm{O}, 300 \mathrm{MHz}\right) \delta: 0.73(\mathrm{t}, 3 \mathrm{H}, J=6.6 \mathrm{~Hz}$, $\mathrm{CH}_{2} \mathrm{CH}_{3}$ ), 1.17-1.19 (m, 4H, $\left.\mathrm{CH}_{2} \mathrm{CH}_{2} \mathrm{CH}_{3}\right), 1.50-1.57$ (m, $2 \mathrm{H}, \mathrm{CH}_{2} \mathrm{CH}_{2} \mathrm{CH}_{2} \mathrm{CH}_{3}$ ), 2.95 (dd, $1 \mathrm{H}$, $\left.J=7.2,14.7 \mathrm{~Hz}, \mathrm{CH}_{2} \mathrm{CH}\right), 3.07\left(\mathrm{dd}, 1 \mathrm{H}, J=4.5,15 \mathrm{~Hz}, \mathrm{CH}_{2} \mathrm{CH}\right), 3.34$ (s, 2H, $\left.\mathrm{SCH}_{2}\right), 4.10-4.18$ $\left(\mathrm{m}, 2 \mathrm{H}, \mathrm{OCH}_{2}\right), 4.28-4.32(\mathrm{~m}, 1 \mathrm{H}, \mathrm{CH}), 7.47\left(\mathrm{~s}, 1 \mathrm{H}\right.$, thymine-6-CH). ${ }^{13} \mathrm{C}$ NMR $\left(\mathrm{D}_{2} \mathrm{O}, 75 \mathrm{MHz}\right)$ $\delta: 168.7,165.8,152.8,141.0,109.5,67.7,61.8,52.3,31.0,27.4,27.2,21.5,13.2$.

\section{CONCLUSIONS}

In summary, the mixture of thionyl chloride and methanol was found to be an efficient reagent for simultaneous deprotection of Boc group and esterification of carboxy group of compound $\mathbf{3}$. Adopting this kind reagent system, the target compound $\mathbf{1}$ and its analogues could be synthesized by two-step method in high yield. It might be a practical and potential approach for the synthesis of other related molecules.

\section{ACKNOWLEDGEMENTS}

The authors are grateful to Dr Qunli Luo and Mr Ning Wang for their assistance in measuring ${ }^{1} \mathrm{H}$ NMR and ${ }^{13} \mathrm{C}$ NMR spectra. We thank the scientific and technological project in Chongqing (No CSTC, 2011AB5001) for financial support.

\section{REFERENCES}

1. Nielsen, P.E.; Egholm, M.; Berg, R.H.; Buchardt, O. Science 1991, 254, 1497.

2. Egholm, M.; Nielsen, P.E.; Buchardt, O.; Berg, R.H. J. Am. Chem. Soc. 1992, 114, 9677.

3. Egholm, M.; Buchardt, O.; Christensen, L.; Behrens, C.; Freier, S.M.; Driver, D.A.; Berg, R.H.; Kim, S.K.; Norden, B.; Nielsen, P.E.; Nature 1993, 365, 566.

4. Nielsen, P.E. Curr. Pharm. Des. 2010, 16, 3118.

5. Nielsen, P.E. Chembiochem. 2010, 11, 2073.

6. Carbonari, M.; Cibati, M.; Sette, N.; Catizone, A.; Fiorilli, M. Methods Cell Biol. 2011, 103, 189. 
7. Nielsen, P.E. Chem. Biodiver. 2010, 7, 786.

8. Kong, L.Q.; Zhao, J.; Fan, L.; Yang, D.C.; Chin. Chem. Lett. 2009, $20,314$.

9. Ma, L.J.; Zhang, G.L.; Chen, S.Y.; Wu, B.; You, J.S.; Xia, C.Q.; Yu, X.Q. J. Peptide Sci. 2005, 11,812 .

10. Wang, X.Y.; Zhang, J.; Li, K.; Jiang, N.; Chen, S.Y.; Lin, H.H.; Huang, Y.; Ma, L.J.; Yu, X.Q. Bioorg. Med. Chem. 2006, 14, 6745.

11. Wang, X.Y. M.Sc. Thesis, Sichuan University, Chengdu, China, 2006.

12. Yang, D.C.; Fan, L.; Zhong, Y.G.. Chin. J. Org. Chem. 2003, 23, 493.

13. Yao, Z.Y.; Yang, D.C.; Fan, L. Chin. J. Med. Chem. 2003, 13, 16. 